\title{
KORELASI PARITAS DENGAN KEMAMPUAN IBU POST PARTUM DALAM MERAWAT BAYI BARU LAHIR
}

\author{
Ervin Zulianti ${ }^{1}$, Umi Aniroh ${ }^{2}$ \\ 1,2 Universitas Ngudi Waluyo \\ umianiroh@unw.ac.id
}

\begin{abstract}
ABSTRAK
Angka kematian bayi di dunia maupun di Indonesia masih tinggi khususnya di Jawa Tengah. Kemampuan ibu sangat penting dalam perawatan bayi untuk kesehatan bayi. Kemampuan ibu merawat bayi bisa dipengaruhi oleh faktor paritas. Tujuan penelitian ini untuk mengetahui hubungan paritas dengan kemampuan merawat bayi baru lahir pada ibu post partum. Penelitian ini merupakan penelitian deskriptif korelasi dengan pendekatan cross sectional,menggunakan alat pengumpul data berupa kuesioner. Populasi dalam penelitian ini ibu post partum. Teknik sampling yang digunakan adalah sampling jenuh dengan 64 responden. Analisis data dilakukan dengan uji kendall's tau. Hasil penelitian menunjukan sebagian besar responden dengan paritas primipara sebanyak 34 responden $(53,1 \%)$ dan sebagian besar responden mempunyai kemampuan merawat bayi baru lahir dalam kategori kemampuan baik sebanyak 56 responden $(87,5 \%)$. Hasil uji statistik dengan kendall's tau diperoleh nilai p-value $0,005(\alpha=0,05)$. Dari analisis statistik tersebut menunjukkan ada hubungan yang signifikan antara paritas dengan kemampuan merawat bayi baru lahir di Wilayah Kerja Puskesmas Kranggan.
\end{abstract}

Kata kunci : Paritas, Kemampuan merawat bayi baru lahir

\begin{abstract}
Infant mortality rates in the world and in Indonesia are still high especially in central Java. Maternal ability is essential in baby care for baby health. The mother's ability of caring for babies can be influenced by parity factors. The purpose of this research to identify the correlation between parity with the ability to care for newborn babies on post partum mothers. The research design was descriptive correlation with cross sectional design approaches. The research instrument used a questionnaires. The population in this research are post partum mother at Kranggan area Community Health Center. The sampling technique used saturated sampling with 64 respondents. Data analysis was done with the Kendall's tau- test. The result showed that most of the respondents with primipara as many as 34 respondents (53.1\%) And most of the respondents have the ability to take care of newborn babies in good category of good show as many as 56 respondents (87.5\%). Based on statistical the result with Kendall's tau show with a p-value $0.005(\alpha=0.05)$, and showed that there is a significant correlation between parities and the ability to care for newborn baby on post partum mother.
\end{abstract}

Keywords: parity, ability to care for newborn baby

\section{LATAR BELAKANG}


Sebagian besar kematian anak di Indonesia saat ini terjadi pada masa baru lahir (neonatal) atau bulan pertama setelah kelahiran. Angka kematian bayi di dunia 29 kematian per 1.000 kelahiran hidup, begitu pula angka kematian bayi di Indonesia masih tinggi dari negara ASEAN lainnya yaitu mencapai 24 per 1000 kelahiran hidup (KEMENKES RI, 2018). Berdasarkan data dari dinas kesehatan Jawa Tengah untuk angka Kematian Bayi di Provinsi Jawa Tengah tahun 2017 sebesar 8,9 per 1.000 kelahiran hidup (Depkes Jateng, 2017). Pada tahun 2017 Di Temanggung ada 19 kematian neonatal dan 26 kematian bayi (Dinkes Temanggung, 2018).

Seiring dengan meningkatnya angka kematian bayi, maka semakin bertambah pula tanggungjawab masyarakat khususnya ibu sebagai orang tua untuk ikut berperan dalam menurunkan angka kematian dan kesakitan pada bayi (Kemenkes RI, 2010). Menurut (Palu, 2019), menandakan bahwa seorang ibu berperan dalam merawat bayinya di rumah melakukan perawatan tali pusat, menyusui bayi, memandikan bayi, mengganti dan mengenakan popok menggendong bayi, memeriksakan kesehatan anak, dan imunisasi. Perawatan yang kurang baik akan berdampak pada pertumbuhan dan perkembangan anak.

Penyakit yang diderita bayi yang paling umum disebabkan oleh bakteri dan virus yang bisa datang dari perawatan bayi yang kurang tepat (Putra, 2012). Risiko infeksi tali pusat pada bayi baru lahir dapat dicegah dengan perawatan tali pusat yang baik (Sodikin, 2009). Oleh karena itu ibu harus menjaga kebersihan bayinya secara keseluruhan untuk mencegah penyakit dengan memandikan bayi dan melakukan perawatan tali pusat pada bayi baru lahir agar bakteri atau virus tidak masuk ke tubuh bayi melalui tali pusat (Sodikin, 2009). Selain personal hygiene, ibu wajib melakukan imunisasi pada bayinya untuk meningkatkan daya imun bayi tersebut dan imunisasi juga merupakan program wajib yang dilakukan di Indonesia yang telah dijelaskan dalam Peraturan Menteri Kesehatan RI No. 42 tahun 2013 tentang Penyelenggaraan Imunisassi (Kemenkes RI, 2010).

Masalah kesehatan bayi dapat menyebabkan bayi rentan terhadap kematian(Meadow S.R dan Newell S.J., 2009). Kematian pada neonatal biasanya diawali dari penyakit yang diderita anak tersebut yang sebenarnya masih bisa ditanggulangi(Meadow S.R dan Newell S.J., 2009). Faktor-faktor risiko kematian bayi di kaitkan dengan faktor bayi, kehamilan dan ibu. Faktor dari ibu seperti usia ibu, pendidikan ibu, paritas yang berhubungan dengan perawatan bayi (Moura dkk., 2014). Menurut (Putri, 2014), kemampuan ibu merawat dalam bayi bisa dipengaruhi oleh tingkat pendidikan ibu, umur ibu, pekerjaan dan juga paritas ibu.

Paritas adalah keadaan melahirkan anak baik hidup ataupun mati, tetapi bukan aborsi, tanpa melihat anaknya. Dengan demikian kelahiran kembar hanya dihitung sebagai satu kali paritas. Sedangkan menurut (Prawirohardjo, 2009), paritas dapat dibedakan menjadi primipara, multipara dan grandemultipara.

Multipara memungkinkan akan lebih siap dan mudah beradaptasi terhadap perannya dalam perawatan bayi baru lahir, seperti hasil penelitian (Afriyanii \& (IJM), 2018),Ada hubungan antara paritas dengan sikap terhadap ASI perah. Paritas berhubungan dengan sikap ibu bekerja terhadap ASI perah untuk keberhasilan menyusui Eksklusif. Pengalaman ibu sebelumnya dapat mempengaruhi sikap positif ibu terhadap ASI perah. 
Menurut (Putri, 2014), apabila ibu mempunyai anak semakin banyak atau lebih dari satu dan semakin tinggi tingkat pendidikan ibu, maka ibu akan lebih mengetahui tentang cara perawatan tali pusat bayi yang baik dan benar.

Berdasarkan hasil studi pendahuluan pada 10 April 2019 di wilayah kerja Puskesmas Kranggan Kabupaten Temanggung jumlah ibu post partum dalam 1 tahun pada 2018 terdapat 335 ibu post partum dan terdapat 3 kematian neonatal dan 6 kematian bayi. Hasil wawancara pada 10 Ibu post partum yang terdiri dari 5 ibu multipara dan 5 ibu primipara, ada empat ibu yang tidak bisa melakukan perawatan bayi dengan baik,ditandai dengan ibu tidak dapat melakukan perawatan tali pusat sampai tali pusat lepas atau puput, sejak kelahiran anak pertama mereka mengandalkan orang tua, dukun atau bidan untuk merawat tali pusat bayinya. Ada tiga Ibu tidak menyusui bayi dengan baik, karena tidak cuci tangan sebelum menyusui, tidak membersihkan payudara terlebih dahulu, dan tidak memberikan ASI Eksklusif. Terdapat tiga ibu untuk perawatan personal hygien kurang baik karena tidak menjaga kebersihan mulut dan kulit bayi, ibu lebih memilih menggunakan diapers dengan menggati diapers 2 kali dalam sehari. Kemudian ada dua ibu tidak datang ke posyandu setiap bulannya untuk penimbangan $\mathrm{BB}$ bayi, namun semua ibu datang ke pelayanan kesehatan untuk mendapatkan imunisasi bayi yang sesuai.

Pada ibu primipara, semua ibu (lima) tidak bisa melakukan perawatan tali pusat, mereka dibantu orang tua, dukun atau bidan untuk merawat tali pusat bayinya. Ada empat ibu tidak menyusui bayi dengan baik seperti tidak melakukan cuci tangan sebelum menyusui, ibu tidak membersihkan payudara terlebih dahulu, dan ibu tidak memberikan ASI Eksklusif. Kemudian terdapat tiga ibu dalam melakukan personal hygiene masih kurang baik karena tidak menjaga kebersihan mulut dan kulit bayi, ibu tidak bisa membedong sendiri masih dibantu orang tuanya, ibu tidak bisa menjaga kehangatan bayi, ibu lebih memilih menggunakan diapers. Semua ibu datang ke posyandu setiap bulannya untuk penimbangan BB bayi, dan datang ke pelayanan kesehatan untuk mendapatkan imunisasi bayi yang sesuai walau dengan didampingi orang tua, suami ataupun saudaranya karena tiga ibu masih takut menggendong bayinya.

Berdasarkan studi pendahuluan terdapat kesenjangan yang tidak sesuai dengan (Putri, 2014), apabila ibu mempunyai anak semakin banyak atau lebih dari satu dan semakin tinggi tingkat pendidikan ibu, maka ibu akan lebih mengetahui tentang cara perawatan bayi yang baik dan benar. Dari permasalahan diatas peneliti tertarik untuk melakukan penelitian untuk mengetahui hubungan paritas dengan kemampuan merawat bayi baru lahir pada ibu post partum di Wilayah Kerja Puskesmas Kranggan, Temanggung.

\section{METODE PENELITIAN}

Jenis penelitian yang digunakan pada penelitian ini adalah deskriptif korelasional dengan pendekatan cross sectional. Populasi dalam penelitian ini adalah ibu post partum di wilayah kerja Puskesmas Kranggan Kabupaten Temanggung pada 2 bulan terakhir (Bulan Agustus \& September 2019) berjumlah 64 ibu post partum.

Teknik sampling dalam penelitian ini adalah teknik sampling jenuh yaitu semua ibu post partum di Bulan Agustus dan September berjumlah 64 responden. Pengambilan sampel pada penelitian ini sesuai dengan ciri-ciri yang sudah ditentukan dalam kriteria inklusi dan ekslusi pada ibu post partum di wilayah kerja Puskesmas 
Kranggan Temanggung. Data diperoleh dengan cara membagikan kuesioner tertutup (closed ended) untuk mengukur kemampuan merawat bayi baru lahir pada ibu post partum dan dilakukan secara door to door.

\section{HASIL DAN PEMBAHASAN}

Tabel 1

Karakteristik Responden ( $n=64)$

\begin{tabular}{lcc}
\hline \multicolumn{1}{c}{ Karakteristik Responden } & $\mathrm{f}$ & $\%$ \\
\hline Umur & 7 & \\
$<20$ tahun & 50 & 10,9 \\
20-35 tahun & 7 & 78,2 \\
$>35$ tahun & & 10,9 \\
\hline Pendidikan & 36 & 56,3 \\
Dasar & 26 & 40,6 \\
Menengah & 2 & 3,1 \\
Tinggi & & \\
\hline Pekerjaan & 8 & 12,5 \\
Bekerja & 56 & 87,5 \\
IRT & & \\
Riwayat Persalinan & 54 & 84,4 \\
Spontan & 10 & 15,6 \\
SC & & \\
\hline
\end{tabular}

Berdasarkan tabel diatas memberikan informasi bahwa usia responden didominasi pada rentang usia 20-35 tahun, pendidikan responden paling banyak pada jenjang pendidikan dasar, status pekerjaan responden sebagian besar adalah ibu rumah tangga dan riwayat persalinan responden terbanyak dengan diwayat persalinan spontan.

Tabel 2

Distribusi Responden Berdasarkan Paritas

\begin{tabular}{ccc}
\hline Paritas & \multicolumn{2}{c}{ Total } \\
\cline { 2 - 3 } & $\mathrm{f}$ & $\%$ \\
\hline Primipara & 34 & 53,1 \\
Multipara & 30 & 46,9 \\
\hline & 64 & 100 \\
\hline
\end{tabular}

Berdasarkan tabel diatas didapatkan sebagian besar responden dengan paritas primipara yaitu $34(53,1 \%)$ dan multipara $30(46,9 \%)$.

Paritas adalah wanita yang pernah melahirkan bayi aterm yang mampu hidup di luar rahim (Manuaba, 2010). Primipara merupakan seorang wanita yang pernah melahirkan bayi hidup untuk pertama kali (Prawirohardjo, 2009). Sedangkan menurut (Hamidiyanti \& Suseno, 2018), primipara adalah wanita yang baru pertama kali mempunyai anak hidup dan baru menjadi seorang ibu. Beberapa ibu primipara biasanya mempunyai keinginan untuk melahirkan bayi yang bebas dari gangguan, sehingga hal tersebut akan memotivasi ibu untuk mencari pengetahuan banyak tentang perawatan maternal.

Berdasarkan hasil penelitian didapatkan hasil sebagian besar umur ibu berusia 20 - 35 tahun yang berjumlah 50 responden $(78,2 \%)$. Usia merupakan salah satu faktor 
yang mempengaruhi kesiapan fisik dan mental seseorang dalam menghadapi masalah. Semakin tinggi umur ibu maka semakin baik pula kemampuan dalam merawat bayi baru lahir dengan benar, karena umur yang cukup disertai dengan pengalaman yang banyak dapat meningkatkan kemampuan ibu dan lebih termotivasi untuk merawat bayi dengan baik dan benar (Sodikin, 2009). Pendapat lain menyatakan bahwa disamping faktor usia, status paritas juga akan berhubungan dengan kemampuan merawat bayi karena pada ibu primipara belum memiliki pengalaman dibandingkan dengan ibu multipara yang sudah memiliki pengalaman dari kelahiran anak pertamanya (Yunita, 2013).

Tabel 3

Distribusi Responden Berdasarkan Kemampuan Merawat Bayi Baru Lahir

\begin{tabular}{ccc}
\hline Kemampuan & \multicolumn{3}{c}{ Total } \\
\cline { 2 - 3 } & $\mathrm{f}$ & $\%$ \\
\hline Cukup & 8 & 12,5 \\
Baik & 56 & 87,5 \\
\hline & 64 & 100 \\
\hline
\end{tabular}

Pada penelitian ini didapatkan hasil bahwa responden banyak yang memiliki kemampuan merawat bayi baru lahir dalam kategori baik dengan jumlah 56 responden $(87,5 \%)$. Dibuktikan dengan hasil kuesioner bahwa sebagian besar responden memeriksa suhu air yang pas (suam-suam kuku) sebelum memandikan bayi (86\%), ibu dapat mempertahankan kehangatan bayi (87\%), ibu menjaga air agar tidak masuk ke lubang hidung, mulut, atau telinga (86\%), menggati popok bayi jika sudah basah dan penuh (89\%), memandikan bayi 2-3 kali dalam sehari $(93,7 \%)$, ibu menyusui pada payudara secara bergantian setelah payudara terasa kosong $(89 \%)$, mengingat macammacam imunisasi dan datang ke posyandu $(95 \%)$.

Menurut(Prawirohardjo, 2009), merawat bayi merupakan hal yang gampanggampang susah, namun walaupun begitu tetap membutuhkan pengetahuan tentang cara perawatan bayi baru lahir. Khususnya ibu yang memiliki anak pertamanya, karena perawatan yang salah bisa menyebabkan dampak negatif bagi bayinya. Banyak faktor yang dapat mempengaruhi pengetahuan seseorang diantaranya usia, pendidikan, pekerjaan, minat, lingkungan,pengalaman, dan informasi. Saat ini dengan adanya perkembangan teknologi setiap calon ibu bisa memperoleh informasi tentang perawatan bayi baru lahir melalui majalah, koran, media elektronik, dan internet tentang perawatan bayi baru lahir, sehingga setiap ibu yang akan mempunyai anak pertama kali sudah siap ketika bayinya sudah lahir.

Responden rata-rata menyelesaikan pendidikan pada tingkat dasar yaitu SD dan SMP yang berjumlah $36(56,3 \%)$ dan memiliki kemampuan merawat bayi baru lahir dalam kategori baik, hal ini menunjukkan bahwa pendidikan tidak mempengaruhi kemampauan ibu dalam merawat bayi, hal ini karena informasi tentang kemampuan merawat bayi tidak diberikan pada pendidikan formal.

Selain dari pendidikan, faktor lain yang mempengaruhi kemampuan dalam merawat bayi baru lahir adalah faktor pekerjaan. Berdasarkan hasil penelitian, karakteristik berdasarkan pekerjaan responden kebanyakan responden tidak bekerja atau hanya sebagai ibu rumah tangga yang berjumlah 56 responden $(87,5 \%)$. Pekerjaan dinilai sebagai hal yang mempengaruhi dalam hal merawat bayinya, didapatkan sebagian besar responden ibu rumah tangga sehingga dengan mudah responden 
melakukan perawatan bayinya, karena bisa fokus melakukan perawatan bayinya sendiri tanpa harus disibukkan dengan pekerjaan lain, berbeda dengan responden yang mempunyai pekerjaan di luar rumah yang tidak dapat fokus dalam merawat bayinya kerena harus membagi waktu dengan pekerjaan lain (Bobak et al., 2009).

Berdasarkan riwayat persalinan, banyak ditemukan ibu post partum yang melahirkan dengan spontan atau normal sejumlah 54 responden $(84,4 \%)$. Menurut Saleha (2009) dalam (Nawati, 2016), kondisi fisik ibu setelah melahirkan dimana semakin cepat kesehatan ibu pulih setelah melahirkan, semakin menyenangkan sikapnya terhadap bayi dan ibu semakin yakin akan kemampuannya untuk melaksanakan peran ibu secara memuaskan. Dalam penelitian ini terdapat ibu dengan riwayat persalinan seksio caesarea sejumlah 10 responden (15,6\%). Menurut (Priscilla, 2013), melahirkan secara operasi seksio membuat ibu merasa takut dalam melakukan perawatan bayi baru lahir dikarenakan ketakutan jika jahitan operasi seksio akan lepas jika ibu melakukan banyak gerakan dalam melakukan perawatan bayi baru lahir. Kemandirian ibu dalam merawat bayi baru lahir sejatinya akan mempercepat kembalinya organ-organ reproduksi ibu seperti semula.

Tabel 4

Hubungan Paritas dengan Kemampuan Merawat Bayi Baru Lahir

\begin{tabular}{lcccc}
\hline \multirow{2}{*}{ Paritas } & \multicolumn{2}{c}{ Kemampuan $(\%)$} & \multicolumn{2}{c}{ Total } \\
& Cukup & Baik & $\mathrm{f}(\%)$ & p-value \\
\hline Primipara & 8 & 26 & 34 & 0,005 \\
& $(23,5)$ & $(76,5)$ & $(100)$ & \\
Multipara & 0 & 30 & 30 & \\
& $(0,0)$ & $(100)$ & $(100)$ & \\
\hline Total & 8 & 56 & 64 & \\
& $(12,5)$ & $(87,5)$ & $(100)$ & \\
\hline
\end{tabular}

Berdasarkan tabel diatas, paritas primipara menunjukkan kecenderungan memiliki kemampuan merawat bayi baru lahir dalam kategori baik yang berjumlah 26 responden (76,5\%). Sedangkan pada paritas multipara keseluruhannya memiliki kemampuan baik yaitu 30 responden $(100 \%)$. Sedangkan nilai signifikansi dalam penelitian ini adalah $p$-value $0,005(<0,05)$ yang berarti ada hubungan antara paritas dengan kemampuan merawat bayi baru lahir

Hal ini sejalan dengan penelitian (Novita, 2018), didapatkan gambaran kemampuan ibu primipara dalam perawatan bayi dikategorikan baik. Menurut Hamidiyanti \& Suseno, 2018), terbentuknya pola perilaku baru dan berkembangnya kemampuan seseorang terjadi melalui tahapan tertentu, yang dimulai dari pembentukan pengetahuan, sikap, sampai memiliki keterampilan baru. Kemampuan ibu merawat bayi baru lahir juga dipengaruhi oleh beberapa faktor yaitu umur, pendidikan, pekerjaan, pengalaman bersalin (paritas), dukungan tenaga kesehatan, dukungan keluarga dan dukungan suami yang terus menerus.

Sebanyak 8 responden $(23,5 \%)$ dengan status primipara memiliki kemampuan cukup. Hal ini dibuktikan dari jawaban kuesioner bahwa perawatan bayi sebagian masih dibantu orang lain seperti orang tua, pengasuh dan bidan. Ada beberapa yang 
mempengaruhi seorang ibu primipara menjadi kurang mampu dalam merawat bayi diantaranya dipengaruhi oleh tingkat pendidikan yang rendah yaitu pendidikan dasar, lamanya usia post partum dan belum adanya pengalaman ibu primipara dalam merawat bayi. Tidak adanya pengalaman, kurangnya pengetahuan, dan ketidakmatangan seseorang untuk menjadi ibu menyebabkan mereka tidak mampu mengenali masalah dan memperoleh sumber daya yang diperlukan untuk memperbaiki situasi. Namun demikian dalam kebanyakan kasus, dengan dukungan yang memadai dan perkembangan pengajaran sesuai, ibu primipara dapat belajar keterampilan pengasuh yang efektif (Maputie, 2010).

Status pekerjaan responden primipara didominasi oleh status tidak bekerja atau hanya sebagai ibu rumah tangga yang berjumlah $56(87,5 \%)$. Seseorang yang bekerja dapat mengembangkan pemikirannya, namun disisi lain pekerjaan juga dapat menganggu peran lain yang dimiliki individu hal ini dapat membuat terjadinya ketidakefektifan peran dalam mengasuh anak.

Responden dengan paritas primipara yang memiliki kemampuan merawat bayi baru lahir dengan kategori baik dapat juga dimungkinkan oleh karena faktor pendukung lainnya, seperti faktor fasilitas pelayanan kesehatan, hal ini dibuktikan dengan sejumlah 51 responden $(80 \%)$ setiap bulan sekali mengikuti kelas ibu hamil. Penelitian yang dilakukan oleh (Wijayanti, 2013), menyatakan keikutsertaan ibu dalam kelas ibu hamil memberikan pengaruh positif pada perilaku ibu dalam merawat bayi baru lahir.

Menurut Bobak (2009) dalam(Hamidiyan , 2015), meskipun banyak ibu primipara yang bahagia dengan proses kelahiran bayi ternyata banyak situasi atau kejadian yang menimbulkan kecemasan. Ibu primipara yang tidak berpengalaman cenderung akan menghadapi masalah kecil atau besar dalam menyesuaikan diri terhadap peran barunya dalam upaya merawat bayi.

Hubungan paritas dengan kemampuan ibu dalam merawat bayi baru lahir bersifat searah atau positif yaitu apabila tingkat paritas semakin tinggi maka semakin tinggi pula tingkat kemampuan ibu merawat bayi baru lahir. Menurut (Putri, 2014), apabila ibu mempunyai anak semakin banyak atau lebih dari satu dan semakin tinggi tingkat pendidikan ibu, maka ibu akan lebih mengetahui tentang cara perawatan tali pusat bayi yang baik dan benar.

Berdasarkan uji korelasi kekuatan hubungan antara paritas dengan kemampuan merawat bayi sebesar 0,36 yang berarti kekuatan hubungan yang lemah. Lemahnya koefisien hubungan paritas dengan kemampuan merawat bayi baru lahir oleh karena kemampuan merawat bayi baru lahir tidak hanya dipengaruhi oleh satu faktor paritas, namun dipengaruhi oleh beberapa faktor lainnya seperti pendidikan, umur, pekerjaan, riwayat melahirkan dan faktor pendukung lainnya seperti dukungan keluarga, tenaga kesehatan, lingkungan dan penggunaan akses media.

\section{SIMPULAN DAN SARAN}

1. Sebagian besar ibu post partum dengan paritas primipara sebanyak 34 responden $(53,1 \%)$.

2. Sebagian besar ibu post partum mempunyai kemampuan merawat bayi baru lahir dalam kategori kemampuan baik sebanyak 56 responden $(87,5 \%)$.

3. Ada hubungan antara paritas dengan kemampuan merawat bayi baru lahir pada ibu post partum dengan nilai $p$-value 0,005 . 
Diharapkan hasil penelitian ini dapat digunakan sebagai bahan acuan untuk penelitian yang lebih luas tidak hanya terbatas pada faktor paritas yang mempengaruhi kemampuan ibu dalam merawat bayi baru lahir,namun juga faktor-faktor seperti pendidikan, umur, pekerjaan, dan faktor pendukung lainnya seperti : dukungan keluarga dan tenaga kesehatan

\section{DAFTAR PUSTAKA}

Afriyanii, L., \& (IJM), N. N. (2018). Paritas Berhubungan dengan Sikap Ibu Bekerja Terhadap Asi Perah di Wilayah Kerja Puskesmas Ambarawa.

Bobak, I., Lowdermilk, D., \& Jensen, M. (2009). Buku ajar keperawatan maternitas.

Depkes Jateng. (2017). Profil kesehatan Profinsi Jawa Tengah Tahun 2017. 3511351(24), 1-112.

Dinas Kesehatan Kabupaten Temanggung. (2017). Profil Kesehtan Tahun 2017 Kabupaten Temanggung. Dinas Kesehatan Kabupaten Temanggung. Retrieved from https://dinkes.temanggungkab.go.id/assets/file/180807040529.pdf

Hamidiyanti. (2015). Pengaruh Tingkat Kecemasan Pada Ibu Postpartum Primipara Remaja Terhadap Kemampuan Pemenuhan Kebutuhan Bayi Baru Lahir di Wilayah Kerja Puskesmas Narmada Kabupaten Lombok Barat NTB.

Kemenkes RI. (2010). Panduan Pelayanan Kesehatan Bayi Baru Lahir Berbasis Perlindungan Anak. Kementerian Kesehatan Republik Indonesia, 1-68.

KEMENKES RI. (2018). Provil Kesehatan Indonesia 2018. https://doi.org/10.1002/qj

Manuaba, I. (2010). Kapita selekta penatalaksanaan rutin obstetri, ginekologi, dan KB. Retrieved from https://www.google.com/books?hl=id\&lr=\&id=C8weUWECoqMC\&oi=fnd\&pg= PA13\&dq=manuaba,+I.B.G.,+kapita+selekta+penatalaksanaan+rutin+obstetri+gi nekologi+dan + Kb.+terbaru\&ots $=$ XBvPOg7q9e\&sig=XnfVxNAqe3q81FOvr6Wt $\mathrm{k} 2 \mathrm{X} 5 \mathrm{IRU}$

Maputie. (2010). Maternal child nursing care.

Maruni. (2012). Inisiasi Menyusui Dini dan Manajemen Laktasi.

Meadow S.R dan Newell S.J. (2009). Lecture Notes: Pediatrika. Edisi 7.

Nawati, N. (2016). Hubungan Status Paritas dengan Tingkat Kemandirian Ibu Post Partum Spontan dalam Perawatan Diri Dan Bayi di RS PMI Bogor. Ejurnal.poltekkes-Tjk.ac.id. Retrieved from http://ejurnal.poltekkestjk.ac.id/index.php/JK/article/view/216

Novita. (2018). Deskriptif untuk gambaran kemampuan ibu primipara.

Nursalam, undefined. (2008). Konsep dan penerapan metodologi penelitian ilmu keperawatan: pedoman skripsi, tesis, dan instrumen penelitian keperawatan.

Palu, A. A. (2019). Pengaruh Tingkat Kecemasan pada Ibu Postpartum Primipara Remaja terhadap Kemampuan Pemenuhan Kebutuhan Bayi Baru Lahir di RSU Anuntapura Palu. Ejournal.stikeswnpalu.ac.id. Retrieved from https://ejournal.stikeswnpalu.ac.id/index.php/JNWNP/article/view/7

Prawirohardjo, S. (2009). Ilmu Kandungan. Edisi 2.

Priscilla, V. (2013). Kemandirian Ibu Postpartum Dalam Perawatan Bayi Baru Lahir dengan Menggunakan Pendekatan Model "Mother-Baby Care (M-BC)." NERS Jurnal Keperawatan, 9(2), 169. https://doi.org/10.25077/njk.9.2.169-176.2013

Putra, S. (2012). Asuhan Neonatus Bayi dan Balita untuk Keperawatan dan Kebidanan. 
Putri, A. Y. (2014). Hubungan Pekerjaan Ibu Dengan Keberhasilan Pemberian AsiEksklusif Pada Anak Di Posyandu BinaPutra Tirto Triharjo Pandak Bantul Yogyakarata. 1-11.

Silaban, A. (2011). Hubungan Tingkat Pengetahuan dengan Kemampuan Ibu Merawat Bayi Baru Lahir Selama Postpartum Dini di Klinik Bersalin Mariani Medan.

Sodikin, M. (2009). Buku Saku Perawatan Tali Pusat. Books.google.com. Retrieved from

https://www.google.com/books?hl=id\&lr=\&id=An8r5THqAyUC\&oi=fnd\&pg=P R5\&dq=Sodikin.+buku+saku+perawatan+tali+pusat.+Jakarta\&ots=DyOAd3g_b3 \&sig=3LRK2To5Q8y-C_CgR4LcqNvw_Q8

Wijayanti, Y. . (2013). PENGARUH KELAS IBU HAMIL TERHADAP PERILAKU IBU DALAM INISIASI MENYUSU DINI DI KOTA METRO Yoga Tri Wijayanti Program Studi Kebidanan Metro Poltekkes Kemenkes Tanjungkarang.

Wulandari, V. (2012). Hubungan Antara Tingkat Pengetahuan Ibu Primigravida Dengan Perilaku Perawatan Payudara Pada Saat Hamil di Wilayah Kerja Puskesmas Karangdowo-Naskah Publikasi.

Yuni Fitri Hamidiyanti, B., \& Rahmawati Suseno, M. (2018). KEMAMPUAN IBU POSTPARTUM PRIMIPARA REMAJA DALAM MENYUSUI BAYI BARU LAHIR DI WILAYAH KERJA UPT BLUD PUSKESMAS NARMADA KABUPATEN LOMBOK BARAT NTB 2017. In Jurnal Kesehatan Prima (Vol. 12). Halaman.

Yunita, M. (2013). Hubungan antaraParitas dengan Tingkat Pengetahuan Ibu tentangPerawatan Tali Pusat Bayi di Ruang Annisa RS PKU Muham-madiyah Surakarta. 